\title{
II. MAHMUD DÖNEMİ NAKŞİBENDİ TEKKE VE ZAVIYYELERİNE YAPILAN YARDIMLAR (1808-1839)*
}

\section{Kübra KARAGÖZ**}

\section{Özet}

Osmanlı Devleti'nin ilk dönemlerinden itibaren tekkeler ibadetlerin yanında hastane, eğitim, barınma, misafirhane veya spor faaliyetleri gibi birçok alanda hizmet vermiş ve nüfuzları giderek artmıştır. Tekkelere gelen misafirlerin çokluğu, şeyhler arasındaki maddi anlaşmazlıklar ve gereksiz harcamalardan kaynaklı zaman zaman tekkeler gelir ve giderler noktasında sıkıntılar yaşamıştır. Sıkıntıların baş göstermesiyle beraber araya gerek devlet gerek vakıflar girerek tekke ve zaviyelerin taamiye, tayinat, fodla, tamir ve onarımları gibi çeşitli ihtiyaçları giderilmiştir. Nitekim bu yardımlar II. Mahmud döneminde de devam etmiş ve tekkeler desteklenmiştir. Yardımlar bazen hazine gelirlerinden bazen gümrük gelirlerinden veya Sultan tarafından vakıfları tek bir yerde toplamak amacıyla 1826 yılında kurulan Evkaf-1 Hümayun Nezareti gelirleriyle de karşılanmıştır. Bu araştırmanın amacl; 1808 ve 1839 yılları arasında Nakşibendi tekke ve zaviyelerine yapılan yardımların neler olduğu, kimler veya hangi kurumlar tarafınca yardımların yapıldığı, yardımların miktarları ve hangi tekkelere verileceği gibi konulara arşiv belgeleri, kaynak ve inceleme eserleri 1şığında değinerek tasnif etmeye çalışmaktır. Ayrıca tekke ve zaviyelerin, dini ritüellerin yanında topluma ve devlete yönelik sosyal ve kültürel alanlardaki çeşitli hizmet faaliyetleri de çalışmada ele alınmıştır.

Anahtar Kelimeler: Devlet, Evkaf-ı Hümayun Nezareti, Nakşibendi Tarikatı, Şeyh, Tekke, Zaviye

\section{AIDS TO NAQSHBANDI TEKKE AND ZAVIYES DURING MAHMUD II PERIOD}

(1808-1839)

\section{Abstract}

Since the first periods of the Ottoman Empire, tekke had served in many areas such as hospitals, education, housing, guesthouses or sports activities as well as worship and their influence had gradually increased. Tekkes experienced difficulties in terms of income and expences from time to time due to the high number of guests coming to the tekkes, financial disputes between the sheikhs and unnecessary expences. With the beginning of the troubles, various needs of the tekke and zaviyes such as taamiye, tayinat, fodla, maintenance and rapair were met thanks to the state and foundations. As a matter of fact these aids continued during Mahmud II period and tekke was supported. Aid was provided sometimes by treasury revenues, sometimes by customs revenues and sometimes by the ministry of Evkaf-i Hümayun. Evkaf-i Hümayun ministry was founded by the Sultan in 1826 to collect the foundations in one place. The purpose of this research; between 1808 and 1839, it is trying to classify the archive documents, sources and works by examining the subjects such as what the aid was made to the Naqshbandi tekke and zaviye, by whom or by which institutions the aid was made, the amount of aid and to which monopoly. In addition to the religious rituals, various services and activities

\footnotetext{
* Bu makale II. Mahmud Dönemi Osmanlı Devleti'nde Nakşibendilik adlı Yüksek Lisans tezinden yararlanılarak üretilmiştir.

"*Kırşehir Ahi Evran Üniversitesi, Sosyal Bilimler Enstitüsü, Tarih Anabilim Dalı Yüksek Lisans Öğrencisi, kbra.krgz06@gmail.com 
of the tekke and zaviyes in social and cultural fields for society and the state will discuss in the study. Zaviye

Keywords: Evkaf-i Hümayun Ministry, Naqshbandi Order, Sheikh, State, Tekke,

\section{Giriş}

Tarikat şeyhleri, irşad vazifesi için gittikleri yerlere çeşitli tekkeler, camiler, medreseler inşa etmiş veya toplum, devlet, ulema ve devlet görevlileri tarafından inşa edilen yapılar tarikatlara bağışlanmıştır. Bu yapılar vasıtasıyla tarikat erbabı devlete ve topluma çeşitli faaliyetler sunarak hizmet etmişlerdir.

Şeyhler, bağlı oldukları tarikatlara ait tekkelerin postnişinlik makamına oturur ve o tarikatın usûl ve erkânlarına dikkat ederek tekkeyi idare ederlerdi. Şeyhlik; babadan oğula geçen veya aynı tarikattan başka birinin tayin edilmesi ile yürütülen bir makamdır. Aynı tarikata bağlı kişiler şeyhleri ile beraber tekkelerde barınarak çeşitli hizmetlerde bulunurlardı. ${ }^{1}$

Tekkeler genellikle harem daireleri, müritlerin kaldıkları hücreler, misafirhaneler, abdesthaneler, mutfak ve halvethaneler gibi bölümlerden oluşurdu. ${ }^{2}$ Muhabbet, sohbet, zikir meclisleri ve ibadet mekânları olarak kullanılan tekkeler bunların yanında barınma, hastane, aşevi gibi çeşitli alanlarda da topluma ve devlete hizmet vermiştir. Mesela Nakşibendi tarikatına ait İstanbul Aksaray Semti'nde ve Üsküdar'da mevcut olan Hindîler Tekkesi Hindistan'dan gelen derviş ve seyyahlar için, ${ }^{3}$ İstanbul Üsküdar'da bulunan yine aynı tarikata ait olan Özbekler Tekkesi Orta Asya'dan gelen misafirlerin barınmaları için ${ }^{4}$ inşa edilmişlerdir. Bir başka örnek ise İstanbul Üsküdar'da bulunan Miskinler Tekkesi olup cüzzamlı hastaların tedavi edilmelerinde kullanılmıştır. ${ }^{5}$ Tekkeler aynı zamanda sanat ve atölye merkezleri olmuştur. Tarikatların kaidelerine uygun olarak yapılan zikirlerde ilahi okunması musiki ve şiir ustalarının tekkelerde yetişmesini sağlamış; tezhip, hat, ebrû, oymacılık, çinicilik, kakmacılık gibi el sanatları tarikatın müritlerine veya tekkeye gelen kişilere öğretilmiştir. ${ }^{6}$ Tekke ve zaviyelerin en önemli hizmetlerinden bir diğeri ise dergâhlar içine kütüphanelerin inşa edilmesidir. Böylelikle tekkelerde ilmî çalışmalar yapılmış, şeyhler veya müritler çeşitli konularda eserler yazmışlardır. Örneğin; Nakşi olan Dahiliye Nazırı Pertev Paşa Üsküdar’da

\footnotetext{
${ }^{1}$ M. Baha Tanman-Sevgi Parlak, "Tekke”, DİA, C.40, Ankara, 2011, s.370-379.

2 Tanman-Parlak, a.g.e., s.370-379; Ömer Yılmaz, Geçmişten Günümüze Tasavouf ve Tarikatlar, Akçağ Yayınları, Ankara, 2019, s.226.

${ }^{3}$ M. Baha Tanman, "Hindîler Tekkesi", DIA, C.18, Ankara, 1998, s.67-69.

${ }^{4}$ M. Baha Tanman, "Özbekler Tekkesi", DİA, C.34, Ankara, 2007, s.123-124.

${ }^{5}$ Nuran Yıldırım, "Miskinler Tekkesi", DIA, C.30, Ankara, 2005, s.185-186; İrfan Gündüz, Osmanlılarda Devlet/Tekke Münasebetleri, Seha Neşriyat, İstanbul, 1989, s.85.

${ }^{6}$ Mustafa Kara, "Tekke", DIA, C.40, Ankara, 2011, s.368-370.
} 
mevcut olan Selimiye Dergahı'na bir kütüphane ilave ettirmiştir. ${ }^{7}$ Aynı zamanda tekkeler spor aktivitelerin yapıldığı mekanlar haline gelmiştir. ${ }^{8}$ İstanbul'daki Okçular (Kemankeş) Tekkesi okçuluk ${ }^{9}$ ve Unkapanı'nda bulunan Pehlivanlar (Güreşçi) Tekkesi ise güreş ${ }^{10}$ gibi spor faaliyetlerine öncülük eden tekkelere örnek gösterilebilir.

Netice olarak tekkeler, ibadetlerin yanında ilim ve irfan meclisleri olmuş, barınma, okul, hastane, misafirhane gibi hizmetlerde faaliyet göstermiştir. Bu tür faaliyetlerini tekke ve zaviyeler kendi vakıf gelirleriyle yürütmüşlerdir. Ancak zamanla devlet bu tür faaliyetlerin devam edebilmesi için birtakım aynî ve nakdî fonlar oluşturarak yardımları gerçekleştirmiştir.

II. Mahmud döneminde de tarikatlara yapılan yardımlar devam etmiş ve ihtiyaçları karşılanmıştır. Özellikle tarikatlar arasında Nakşilere ayrı bir ehemmiyet verilmiş hatta yapılan yardımlarda Nakşiler ön planda tutulmuştur. Devletin Nakşilere karşı bu tutumu; devlet adamları ve toplum tarafından Nakşilerin sevilip desteklenmesi, tarikatın güçlü bir nüfusa sahip olması, geniş bir bölgeye yayılmaları gibi öncüllerden kaynaklı olduğu söylenilebilir. Buradan yola çıkarak bu çalışmada, II. Mahmud döneminde devlet tarafından Nakşi tekke ve zaviyelerine yapılan yardımların neler olduğu, kimler tarafından yardımların yapıldığı, yardımların miktarları ve hangi tekkelere verilecekleri gibi konular üzerinde durulacaktır. Ayrıca 1826 yılında kurulan Evkaf-1 Hümayun Nezareti'nin tekkelere ne gibi hizmetler sağladığı konusuna da değinilecektir. Çalışmada konu, Cumhurbaşkanlığı Osmanlı Arşiv belgeleri, kaynak ve inceleme eserleri ışı̆̆ında ele alınmıştır.

\section{Nakşi Tekke ve Zaviyelerine Yapılan Çeşitli Erzak Yardımları}

Osmanlı Devleti'nin kuruluşundan itibaren padişahlar, devlet adamları ve maddi durumu iyi olan kimseler Osmanlı topraklarında çeşitli hanlar, medreseler, tekkeler, hamamlar ve camiler yaparak hayır işlerinde bulunmuşlardır. Bu yapıtların idaresini ve devamını sağlayabilmek adına da çeşitli vakıflar kurmuşlardır. ${ }^{11}$ Kurmuş oldukları vakıflar aracılığıyla aynı zamanda medrese öğrencilerinin, tekkelerin, müderrislerin, aşevlerinin günlük ihtiyaçlarını, gelir ve giderlerini de karşılamışlardır. ${ }^{12}$

\footnotetext{
${ }^{7}$ Hür Mahmud Yücer, Osmanlı Toplumunda Tasavvuf (XIX. Asır), İnsan Yayınları, İstanbul, 2002, s.76.

${ }^{8}$ Mustafa Kara, Tekkeler ve Zaviyeler, Dergah Yayınları, İstanbul, 2005, s.40; Gündüz, a.g.e., s.85.

${ }^{9}$ Filiz Gündüz, "Okmeydanı”, DİA, C.33, Ankara, 2007, s.339-340.

${ }^{10}$ Abdülkadir Özcan, "Güreş", DİA, C.14, Ankara, 1996, s.317-320.

${ }^{11}$ Ekrem Özer, Osmanlı'da Tekke ve Tarikat Islahatları II. Mahmud Dönemi ve Sonrası, Atatürk Üniversitesi Sosyal Bilimler Enstitüsü, Doktora Tezi, Erzurum, 2007, s.78.

${ }^{12}$ Hacı Mehmed Günay, "Vakıf”, DİA, C.42, Ankara, 2012, s.475-479; Ayrıca bkz. Şakir Berki, "Vakıfların Gördüğü Çeşitli Hizmetler", Vakıflar Dergisi, S.6, 1965, s.86-91.
} 
Vakıflar, başlangıçtan 16. yüzyılın sonlarına kadar sultanlar ve idareci zümrelerin himayeleri altında iken 17. yüzyıldan itibaren vakıf zümrelerinde farklılık yaşanmaya başlamıştır. Özellikle 18. yüzyılda merkezi otoritenin zayıflamasıyla beraber merkez ile taşra arasındaki dengeler bozulmuş ve etkileri vakıflar üzerinde de tesirli olmuştur. Devlete ait olan elverişli araziler taşra yöneticilerinin, ayan ailelerinin özel mülkü olmuş ve bu araziler daha sonraları kendilerine ve yakınlarına ait olmak üzere vakfa dönüştürülmüştür. 19. yüzyıla gelindiğinde ise II. Mahmud vakıflar ile ilgili çeşitli düzenlemeler yapmaya başlamıştır. Çünkü bazı kişilerin vakıfları, kendi menfaatleri doğrultusunda aile ve yarı aile vakfı haline getirerek kullanmaya başlamaları, giderek yolsuzluğun artmasına neden olmuş ve bu durum üzerine sultan harekete geçmiştir. ${ }^{13}$

II. Mahmud dağınık bir vaziyette bulunan vakıfları tek bir yerde toplamak ve vakıf yönetimindeki yolsuzluğu önlemek gibi pek çok amaçtan hareketle 14 Ekim 1826'da Evkaf-1 Hümayun Nezareti'ni kurmuş ve vakıfları bu nezarete bağlamıştır. ${ }^{14} \mathrm{Bu}$ nezaretin kurulmasıyla beraber bu durumdan en çok etkilenen kesim şüphesiz tekkeler ve tarikatlar olmuştur. Çünkü vakıflar, tekkelerin idaresi ve kontrolü altında olup hizmet etmekteydi. Tekkelerin hizmetinde olan vakıfların yetkileri ellerinden alınmış ve gelirleri nezaret aracılı̆̆ıyla toplanarak eşit şekilde paylaştırılmıştır. Tekke ve zaviyelerin gelir aktarımını sağlayan vakıflar böylece devletin tekeline geçerek kontrol altına alınmıştır. ${ }^{15}$

Tekkelerin gündelik ihtiyaçları, taamiyeler, kurbanlık koyun ve et tayinatı, Mevlid ve Mirac Kandilleri için verilen tayinat gibi yardımlar ile tekke bakım, onarım ve inşaları da bu nezaret gelirleri vasıtasıyla yapılmıştır. ${ }^{16}$ Ayrıca bu yardımların bir düzen içerisinde, zamanında ve kontrol dahilinde olabilmesi için bazı bölgelerin gümrük gelirlerine ${ }^{17}$ veya Sultan Mahmud'un son zamanlarında kurulan Harameyn Vakıfları' na ${ }^{18}$ ya da toplanılan zekatlar,

\footnotetext{
${ }^{13}$ Mehmet İpşirli, "II. Mahmud Dönemi Vakıfların İdaresi", Sultan II. Mahmud ve Reformları Semineri, İstanbul, 1990, s.49-51.

${ }^{14}$ Nazif Öztürk, “Evkaf-1 Hümayun Nezareti”, DIAA, C.11, Ankara, 1995, s.521-524; M. Fuat

Köprülü, "Vakıf Müessesesinin Hukuki Mahiyeti ve Tarihi Tekamülü", Vakıflar Dergisi, S.2, 1942, s.23-24.

15 Özer, a.g.e., s.84.

${ }^{16}$ Zekeriya Işık, Tekkedeki Iktidar, Çizgi Yayınları, Konya, 2017, s.119.

${ }_{17}$ Muharrem Varol, Bektaşilik İlgası Sonrasında Osmanlı Devleti'nin Tarikat Politikaları (1826-1866), Marmara Üniversitesi Türkiyat Araştırmaları Enstitüsü, Doktora Tezi, İstanbul, 2011, s.148.

18 İsimleri belirtilmeyen İstanbul'daki on beş tekke ve zaviyeye Harameyn Hazinesi'nden yedi yüz yetmiş beş guruş taamiye tahsisi yapılmıştır. BOA, HAT, 1320/51539, H. 29.12.1253 (M. 26 Mart 1838).
} 
bağışlar, sadakalar gibi çeşitli gelir kaynaklarına dayanması sağlanmıştır. ${ }^{19} \mathrm{Bu}$ sayede bir ayda veya bir günde, ne miktarda, nereden gelir elde edileceği bilinir kılınmıştır. Tekke vakıfları da bu gelir kaynaklarından ne kadar para veya yardımın geleceğini bildiği için bütçelerini ona göre belirlemişlerdir. ${ }^{20}$ Teoride nezaret, vakıfların tüm ihtiyaçlarını karşılayacaktı. Ancak pratikte bu tam olarak gerçekleşemedi ve vakıfların birçoğu ihtiyaçlarını karşılayamadılar. Üstelik bazı vakıflar, maddi yetersizlik yüzünden harap olmuş ve hizmetlerini yerine getirememişlerdir. ${ }^{21}$

19. yüzyılda Nakşibendi tarikatının dergahlarına ve zaviyelerine yapılan yardımların başında taamiye gelmektedir. Taamiye; tekke ahalisi, fakirler veya tekkeye gelen misafirlerin yeme, içme gibi temel ihtiyaçlarının karşılanabilmesi için verilen bedelin ismidir. ${ }^{22}$ Nakşi zaviyelerine ve tekkelerine Matbah-1 Amire ağası tarafından taamiyeler teslim edilirdi. ${ }^{23}$ Verilen taamiyeler kaydedilir ve teslim edildiklerine dair bir de makbuz verilirdi. ${ }^{24}$ Verilen makbuzun amacı, herhangi bir usûlsüzlüğe engel olmak ve maddi denetimi kontrol altında tutmaktır.

Nakşi dergahlara verilen taamiyeler; tekkelerin işlevleri, nüfusları, büyüklükleri veya hazineden ayrılan bütçeye göre değişiklik göstermiştir. ${ }^{25}$ Ayrıca Nakşi tekkelerinin taamiyeleri tekke ahalisine veya misafirlerine yetersiz gelmesi halinde devlet veya vakıflar taamiye miktarlarına, tutarlarına zam da yapmışlardır. ${ }^{26}$ Nakşibendi tekke ve zaviyelerine devlet ve vakıflar tarafından verilen taamiyelerin bazen çeşitli bölgelerin gümrük gelirlerinden ${ }^{27}$, Haremeyn

\footnotetext{
${ }^{19}$ Hasan Küçük, Osmanlı Devleti'ni Tarih Sahnesine Çıkaran Kuvvetlerden Biri; Tarikatlar ve Türkler Üzerindeki Müsbet Tesirleri, TÜRDAV Yayınları, İstanbul, 1976, s.140-141.

${ }^{20}$ Mustafa Özsaray, Arşiv Belgeleri Iş̧̆̆ı̆nda Osmanlı'da Devlet-Tekke İlişkileri (XIX. Yüzyıl), Fatih Sultan Mehmet Vakıf Üniversitesi Sosyal Bilimler Enstitüsü, Doktora Tezi, İstanbul, 2018, s.285. ${ }^{21}$ İpşirli, a.g.e., s.57.

${ }_{22}$ Mehmet Zeki Pakalın, "Taamiye", Osmanlı Tarih Deyimleri ve Terimleri Sözlüğü̈, MEB, C.3, İstanbul, 1983, s.363; Ethem Cebecioğlu, "Ta'am", Tasavouf Terimleri ve Deyimleri Sözlüğ̈̈, Rehber Yayınları, Ankara, 1997, s.679; Tekke ve zaviyelere tahsis edilen taamiyelerle alakalı çok sayıda belge mevcuttur. Bazıları için bkz. BOA C.EV.., 224/11195; C.EV..., 231/11501.

${ }^{23}$ Matbah-1 Amire emini tarafından Kemankeş (Okçular) Tekkesine verilen taamiyeler için bkz. BOA, C..BLD., 9/447, H. 23.06.1235 (M. 7 Nisan 1820).

${ }^{24}$ BOA, C..ML.., 15/658, H. 23.08.1249 (M. 5 Ocak 1834).

${ }^{25}$ Varol, a.g.e., s.147.

26 Bağdad Kazası'nın Gülanber Kasabası'nda bulunan Nakşi Gülanber Tekkesi'ne gelen gidenlerin fazla olması ve verilen taamiyenin yeterli miktarda olmamasından ötürü zam yapıldı ğına dair bkz. BOA, C.EV..., 244/12198, H. 13.03.1234 (M. 10 Ocak 1819).

${ }^{27}$ Kudüs'te Mescid-i Aksa yanında bulunan Nakşibendi Tekkesine Yafa Gümrüğü'nden yevmi otuz beş akçe taamiye tahsis edilmiştir. BOA, HAT, 1513/73, H. 29.12.1225 (M. 25 Ocak 1811).
} 
Hazinesi'nden, mukataalardan ${ }^{28}$ veya Tersane-i Amire $^{29}$ ambarından karşılanmıştır. ${ }^{30}$

Tekke şeyhlerinin, halifelerin veya misafirlerin yeme içme ihtiyaçlarının tutarları için verilen taamiyeler bazen de Nakşi şeyhlerinin veya dervişlerin fakir hallerine binaen onlara tahsis edilmiş olduğu belgelerden anlaşılmaktadır. ${ }^{31}$ Şeyhlere tahsis edilen taamiyeler, tekke şeyhinin vefat etmesi veya başka sebeplerden ötürü şeyhin taamiyesini alamadığ zamanlarda şeyhin ailesi veya şeyhlik yaptığı tekkedeki halifeleri devreye girmişlerdir. Şeyhin yakınları ve halifeleri bu tahsis edilen taamiyenin tekke ve zaviye taamiyesi olarak devam etmesini istemişlerdir. Böylece tekkede kalanların ihtiyaçları giderilmiş ve daha önce devam eden taamiye tahsisinin kesilmesi engellenmiştir. ${ }^{32}$

II. Mahmud, tekkelere tahsis edilen taamiyelere yönelik çeşitli denetim mekanizmaları kurmuştur. Örneğin taamiye verilecek tekke ve zaviyeler Sultan'ın emriyle maddi gücü, nüfusu, dergahın ehl-i sünnetten bir tarikata ait olup olmadığı ve taamiye tahsisi noktasında ihtiyacının olup olmadığı gibi hususlar gizlice incelenmiştir. ${ }^{33}$

Nakşibendi tekkelerine yapılan yardımlardan bir diğeri ise fodla yani ekmektir. ${ }^{34} \mathrm{Bu}$ ekmekler, Sultan II. Mahmud'un emriyle Tophane'den ve arabacılar fırınlarından günlük olarak, dergahlara, salihlere ve fakir fukaraya verilmiştir. ${ }^{35}$ Fodla dişında Nakşi tekke ve zaviyelerine yemeklik tuz da dağıtılmıştır. ${ }^{36}$

Osmanlı Devleti'nin eski bir geleneği olan zaviyelere kurbanlık koyun ve günlük et tayinatı II. Mahmud döneminde de devam etmiştir. Savaş, hastalık gibi durumların hayırla sonuçlanması veya bitmesi niyetiyle devlet tarafından

\footnotetext{
${ }^{28}$ Nakşibendi tarikatına ait olan bir tekkeye Adana İhtisabı Mukaatasından taamiye tahsisi yapıldığı görülmektedir. BOA, C.EV.., 139/6946, H. 09.07.1225 (M. 30 Ağustos 1810).

29 İdris Bostan, “Tersane-i Amire", DIA, C.40, Ankara, 2011, s.513-516.

${ }^{30}$ Varol, a.g.e., s.148-149.

${ }^{31} \mathrm{Bu}$ hususta pek çok örneğe rastlamak mümkündür. Misal; Bağdad'da Gülanber Kasabası'nda mevcut olan Nakşilere ait olan Gülanber Tekkesindeki dervişlerin fakir hallerine binaen kişi başına yevmi altmış ikişer taamiye tahsis edilmiştir. BOA, HAT, 544/26892, H. 29.12.1229 (M. 12 Aralık 1814).

32 Varol, a.g.e., s.151.

${ }^{33}$ İstanbul Anadolu Hisarı'nda bulunan Şeyh Mehmed Rumî Tekkesi şeyhi Ali Efendi taamiye isteğinde bulunmuştur. Bunun üzerine II. Mahmud Şeyhülislam'a bu şeyhin ve tekkenin araştırılmasını emretmiştir. Şeyhülislam tarafından hazırlanan raporda; Şeyh Ali Efendi'nin Nakşibendi tarikatı ahalisinden fakir biri olduğu ve kötü bir niyetinin olmadığı belirtilmiştir. BOA, HAT, 553/27361, H. 29.12.1252 (M. 6 Nisan 1837).

${ }^{34}$ Feridun Emecen, "Fodula" DİA, C.13, Ankara, 1996, s.167-170.

${ }^{35}$ BOA, C.BLD..., 43/2143, H. 04.03.1244 (M. 14 Eylül 1828).

${ }^{36}$ BOA, C.EV.., 242/12061, H. 22.05.1229 (M. 12 Mayıs 1814).
} 
Nakşi tekkelerine kurban bağışı yapılırdı. ${ }^{37}$ Ayrıca her sene Kurban Bayramı'nda da devlet, bu tekkelere saray ahalisi için kurban dağıtılırdı. ${ }^{38}$ Kurban Bayramı için dağıtılan koyunlar hassa kasapbaşısının vazifesidir. Hassa kasapbaşısı tekkelerdeki şahıs sayısına göre koyun tahsisi yapmış ve bazı tekkelere bir koyun verilirken bazı tekkelere ise daha fazla koyun verilmiştir. ${ }^{39}$ Nakşi tekkelerine verilen kurbanlık koyun dışında devlet, bazı dergahlara Mansure Hazinesi yönetiminde günlük lahm (et) tahsisi de yapmıştır. ${ }^{40}$ Bir örnek olayda 28 Nisan 1835 tarihinde Bab-1 Hümayun yanında mevcut olan Nakşibendi Dergahına iki kıyye et tahsisinin yapıldığı görülmektedir. ${ }^{41}$

Nakşi tekke ve zaviyelere yapılan erzak yardımlarından diğerleri ise hınta (buğday) ${ }^{42}$ ile tekke mensubu kişilerin binekleri için arpa-saman ve pirinç tayinatıdır. Tekke ve zaviyelere verilen hınta bazen tekke ahalisine yetmemiş ve devlet hıntanın miktarını arttırmıştır. ${ }^{43}$ İstanbul'da bulunan bazı tekke mensuplarının binekleri için Anbar-1 Amire'den karşılanmak üzere arpa ile saman tayinatı da yapılırd1. ${ }^{44}$ Pirinç tayinatı ise devlet tarafından Matbah-1 Amire' den, ${ }^{45}$ mukataalardan veya vakıflardan temin edilerek Nakşi tekkelerine dağıtılmaktaydı. Örnek olarak, Üsküdar Sultantepesi'ndeki Nakşibendi Dergahına bir kıyye ${ }^{46}$ ve Edirne'de bulunan Arabzade Şeyh Mehmed Efendi Tekkesine ise on kile pirinç tayinatı yapılmıştır. ${ }^{47}$ Yemeklerin pişirilmesi için kullanılan yağ da (tereyağ) devlet tarafından tekkelere tahsis edilmiştir. ${ }^{48}$ Ayrıca devlet, yaz aylarının sıcak geçmesinden dolayı yiyecek ve içeceklerin

\footnotetext{
${ }_{37}$ Ömer Lütfi Barkan, Osmanlı İmparatorluğu'nda İmaret Sitelerinin Kuruluş ve İşleyiş Tarzına Ait Araştırmalar, İstanbul Üniversitesi İktisat Fakültesi Mecmuası, C.23, 1962-1963, s.274-276; Varol, a.g.e., s.160; BOA, C.ML.., 780/31853, H. 29.12.1236 (M. 27 Eylül 1821).

38 Zekeriya Işıı, Şeyhler ve Şahlar, Çizgi Yayınları, Konya, 2015, s.24-25.

${ }^{39}$ BOA, C.SM.., 32/1620, H. 05.12.1233 (M. 6 Ekim 1818).

${ }^{40}$ BOA, HAT, 527/25869, H. 29.12.1250 (M. 28 Nisan 1835).

${ }^{41}$ BOA, HAT, 1302/50752, H. 29.12.1250 (M. 28 Nisan 1835).

${ }^{42}$ Eski Kandiye Muhafızı Derviş Abdullah Paşa, Kandiye'de inşa edilen Nakşibendi tekkesine hınta (buğday) tahsisi yapılması için Sadrazam'a yazdığı dilekçe için bkz. BOA, HAT, 719/34281, H. 25.02.1225 (M. 1 Nisan 1810).

${ }^{43}$ Edirne'de mevcut olan Kaplan Baba Kadiriyye Tekkesine, Edirne Ada Mukataasından verilen buğdayın tekke erbabına yeterli gelmemesinden kaynaklı buğday bedeli arttırılmıştır. BOA, C.EV.., 561/28306, H. 15.11.1250 (M. 15 Mart 1835); Başka örnekler için bkz. C.EV.., 152/7570; AE. SMHD.II, 93/7775.

${ }^{44}$ Varol, a.g.e., s.166-167.

${ }^{45}$ Arif Bilgin, "Matbah-1 Amire", DIA, C.28, Ankara, 2003, s.115-119.

${ }^{46}$ BOA, C.EV.., 298/15173, H. 30.07.1224 (M. 10 Eylül 1809).

47 BOA, C.EV.., 345/17546, H. 14.07.1244 (M. 20 Ocak 1829); Bu konuyla alakalı çok sayıda belgeyle karşılaşmak mümkündür. Bazıları için bkz. C.EV.., 332/16863; C.EV.., 423/21417; C.EV.., 530/26764; TS.MA.e, 1171/1.

${ }^{48}$ BOA, C.ML,, 77/3502, H. 11.10.1226 (M. 29 Ekim 1811); C.EV.., 137/6807, H. 13.10 .1230 (M. 18 Eylül 1815).
} 
soğuk tutulmalarını sağlayabilmek adına II. Mahmud'un emriyle bazı tekke ve medreselere, saray ahalisine kar ve buz dağıtımı yapmıştır. ${ }^{49}$ Tekkelere tahsis edilen kar ve buz Hazine-i Hassa tarafından dağıtılırdı..$^{50}$

Nakşi tekkelerine devlet tarafından fodla, taamiye, et, kurbanlık koyun ve pirinç gibi yapılan yardımların temelde birçok nedeni vardır. Devlet, ulaştırdığı bu yardımlar vasıtasıyla tekkeleri kontrol ederek denetleyebilmiştir. Böylelikle tekkelerde yaşanan herhangi bir usûlsüzlük veya yolsuzluk gibi meselelere devlet hemen müdahale edebilmiş ve gerekli önlemler alabilmiştir. Ayrıca Nakşibendi tarikatının toplumsal düzende nüfuzundan yararlanmak, yapılacak reformlarda desteklerini almak, devletin bekası için şeyhlerden dua istemek ${ }^{51}$ ve padişahın toplum ve tarikat üzerindeki saygınlı̆̆ını arttırmak da devlet tarafından yapılan yardımlar ile hedeflenmiştir. ${ }^{52}$

\section{Muharremiyye, Mevlid ve Mirac Kandilleri İçin Tayinat Verilmesi}

Hz. Muhammed'in Mekke'den Medine'ye hicreti resmî takvim başlangıcı olarak kabul edilmiş ve muharrem hicrî yılın ilk ayı olarak belirlenmiştir. ${ }^{53}$ Hicrî ve Kameri ayların ilk ayı ve yeni senenin başı olan Muharrem ayı münasebetiyle tebrik amaçlı manzumeler yazılır, tekke ve camilerde ilahiler okutularak çeşitli kutlamalar yapılırdı. ${ }^{54}$ II. Mahmud'un emriyle de yeni senenin başlangıcı için Muharremiyye adıyla çeşitli tekkelere ve tekkelerdeki tarikat mensubu kişilere her yil hediyeler veya paralar Haremeyn Hazinesi'nden karşılanarak dağıtılırd1.$^{55}$ Nitekim, 1821 yılına ait bir kayıtta muharremiyelerin dağıtılmasının amacı devletin devamlılığ ve sultanın şahsı için tarikat erbabının duasını almak olduğu vurgulanmıştır. ${ }^{56}$ Ayrıca devlet muharremiyeler vasitasıyla tekke ahalisinin gönüllerini hoş tutmuş ve yeni senelerini tebrik etmiştir. ${ }^{57}$ Devlet ve tarikatın bu karşılıklı ilişkileri iki tarafın da lehine olmaktadır. Çünkü devlet meşruiyet ve toplumsal destek kazanırken tarikat ise maddi bir güç kazanmanın yanında devletin desteğini halka

\footnotetext{
${ }^{49}$ Galata Mevlevihanesi'nde vazifeli olan şeyhe, Ağustos sonuna kadar günlük bir denk kar verilmesi II. Mahmud tarafından emredilmiştir. BOA, AE. SMHD.II., 64/4585, H. 05.07 .1230 (M. 13 Haziran 1815); Özsaray, a.g.e., s.282.

50 Varol, a.g.e., s.166.

51 Özsaray, a.g.e., s.302.

52 Varol, a.g.e., s.188-189, 209.

${ }^{53}$ M. Kamil Yaşaroğlu, "Muharrem”, DİA, C.31, Ankara, 2006, s.4-5.

${ }^{54}$ Pakalın, "Muharremiyye", a.g.e., C.2, s.566-567; Yaşaroğlu, a.g.e., s.4-5.

${ }^{55}$ Muharrem ayı vesilesiyle tekke ve zaviyelere dağıtılan muharremiyyeler için bkz. BOA, HAT, 1553/45; HAT, 1568/44; HAT, 1652/1; AE. SMHD.II., 115/9705.

56 İstanbul'da bulunan tekkelere Muharrem ayının ilk günü hasebiyle iki bin dört yüz guruş Haremeyn Hazinesi'nden tahsis edilmiş ve bu tekkelerden padişah için dua edilmesi istenmiştir. BOA, IE.HAT, 6/573, H. 29.03.1237 (M. 24 Aralık 1821); Bir başka vesika için ayrıca bkz. IE.HAT, 6/588, H. 15.01.1239 (M. 21 Eylül 1823).
}

${ }^{57}$ Varol, a.g.e., s.155. 
göstererek hem kendi gücünü hem de devlet nezdindeki etkinliğini halka göstermiş olmaktadır.

Mevlid-i Şerif ${ }^{58}$ ve Miraç Kadilleri'nde ${ }^{59}$ devlet desteğiyle tekkelerde ve camilerde çeşitli ibadetler ve ayinler yapılmıştır. ${ }^{60}$ Dergahlarda ve camilerde yapılan çeşitli programlara padişah, devlet erkanı ve halk katılmıştır. Bu çeşitli etkinliklerin masrafları bazen vakıflar tarafından bazen de devlet tarafından karşılanarak tekkelere ödemeler yapılmıştır.61 Özellikle Hz. Peygamber'in doğumu münasebetiyle icra edilen Mevlid-i Şerif kandilinde bazı tekke ve zaviyelerde yapılan etkinliklerin devlet tarafından detaylı bir şekilde planlanmasına önem verilmiştir. ${ }^{62}$ Mevlid-i Şerif kandili için merasim yürüyüşü yapılmış, bütün minarelerin kandilleri yakılmış ve tekkelerde, camilerde, medreselerde mevlid kıraatinde bulunulması emredilmiştir. ${ }^{63}$ Nitekim devlet, kandil programları vasıtasıyla toplum ve tarikat erbabı üzerinde iyi yönde bir etki bırakarak onların teveccühünü kazanmıştır. Ayrıca, böyle programlar tekke ve dergahların devlete olan bağlllıklarını pekiştirici birer araç olmuşlardır. ${ }^{64}$

\section{Yolculuk ve Hac İçin Sağlanan Kolaylıklar}

Tekke şeyhleri ve halifeleri irşad faaliyetlerinde bulunabilmek, tasavvuf öğretilerini insanlara aktarabilmek, başka bir tekkeyi ziyaret etmek veya memleketlerine gitmek gibi çeşitli sebeplerden dolayı farklı ülkelere ve şehirlere seyahat etmişlerdir. Sultan II. Mahmud, seyahat için yola koyulan tekke erbabının yol boyunca güvenliklerini sağlamak adına çeşitli askeri tedbirler aldırmış hatta şeyhlere gidecekleri yerlerde kolaylık sağlanması veya hürmet edilmesi adına yol emri vermiştir. Verilen yol emri neticesinde tekke erbabının gittikleri yerlerde yeme-içme, binek hayvanı veya barınma gibi çeşitli ihtiyaçları karşılanmaktaydı. ${ }^{65}$ Ayrıca ulaşımda deniz yolunu tercih eden

\footnotetext{
58 Ahmet Özel, "Mevlid", DİA, C.29, Ankara, 2004, s.475-479; Mehmet Şeker, "Mevlid", DİA, C.29, Ankara, 2004, s.479-480.

59 Salih Sabri Yavuz, "Mirac", DİA, C.30, Ankara, 2005, s.133-135; Mustafa İsmet Uzun, "Miraciyye", DİA, C.30, Ankara, 2005, s.135-140.

${ }^{60}$ Halide Aslan, "Osmanlı İmparatorluğu'nda Mübarek Gün ve Gecelerden Kandiller", ÍSTEM, S.13, Konya, 2009, s.199-231.

${ }^{61}$ Arşivdeki bazı belgelerden belli başlı tekkelerde kandil için yapılan ibadet ve ayinlerin devlet tarafından ne şekilde desteklendiklerini görmekteyiz. Örneğin; İstanbul Horhor'da bulunan Nakşibendi tarikatına ait olan Hindiler Zaviyesine, Halil Hamid Paşa Evkafı'ndan elli kuruş verilerek Mevlit-i Şerif kıraatinde bulunulmuştur. BOA, C.EV.., 226/11280, H. 21.04.1228 (M. 23 Nisan 1813); Varol, a.g.e., s.157.

62 Varol, a.g.e., s.158.

63 Şeker, a.g.e., s.479-480.

${ }^{64}$ Varol, a.g.e., s.156.

${ }^{65}$ Pek çok örnekten sadece bir tanesi; Abdülkadir Geylani sülalesinden olan, Şeyh Abdülcebbar Tekkesi şeyhine yol emri verilmesi ve çeşitli ihtiyaçlarının giderilmesi için bkz. BOA, C.DH.., 70/3496, H. 24.07.1224 (M. 4 Eylül 1809); Özsaray, a.g.e., s.257.
} 
şeyhlere de devlet kumanya ve navlun ${ }^{66}$ ücretleri vererek rahat yolculuk etmelerini sağlamaktayd $1 .{ }^{67}$ Bir de şeyhlere, yevmiye veya yol masraflarını karşılayabilmeleri için yol parası adı verilen harcırah devlet tarafından temin edilmiştir. $^{68}$

Hadimü'l-Haremeyn unvanını Yavuz Sultan Selim Han'dan itibaren alan Osmanlı Sultanları'nın hac vazifesi için yola koyulan şeyhlerin, müritlerin veya halktan kişilerin güvenliklerini sağlamak en büyük sorumluluklarından birisi olmuştur. ${ }^{69}$ Hac ibadetini gerçekleştirmek için yola çıkan şeyhlere de Padişah'ın emriyle yol emri verilmiştir. ${ }^{70}$ Hac güzergah yolu üzerinde yaşamların idâme ettiren Arap bedevileri, hac yolunu ve coğrafyayı iyi bildiklerinden zaman zaman hac kervana saldırmışlar ve hacıların mallarına, paralarına el koymuşlardır. Osmanlı Devleti hacıların yaşadıkları sıkıntıları göz önünde bulundurarak bedevilere "surre" adı verilen içine akçe veya dinar koyulan para keseleri göndererek onlarla anlaşmıştır. Bedeviler böylelikle aldıkları surreler ile hac yolculuğunda hacılara yardımcı olarak onların ihtiyaçlarını gidermişlerdir. Söz konusu surreler şayet vaktinde verilmez veya gönderilen surrelerin miktarı bedevileri memnun etmezse, bu Arap bedevileri hac kervanına saldırarak zarar vermeye devam etmişlerdir. ${ }^{71}$

II. Mahmud hac yolculuğuna çıkan şeyhlerin, dervişlerin ve ahalinin dinlebilmeleri için hac yolu güzergahına tekkeler ve kervansaraylar ${ }^{72}$ da inşa ettirmiştir. Örneğin; Üsküdar'da bulunan Özbekler Tekkesi, Orta Asya'dan hac için gelen dervişlerin ihtiyaçlarını giderebilmek ve hac dönüşünde konaklamalarını sağlayabilmek için Sultan emriyle inşa edilmiştir. ${ }^{73}$

\section{Tekke İnşaları (Tamir ve Onarım)}

II. Mahmud, kendinden önceki Osmanlı sultanları gibi tekke inşa ve tamir işlerine ehemmiyet vererek özen göstermiştir. Tekke ve devlet arasındaki

\footnotetext{
${ }^{66}$ Gemi için alınan taşıma ücretidir. Mehmet Ali Ünal, "Navlun”, Osmanlı Tarih Sözlü̆ğü, Paradigma Yayıncllık, İstanbul, 2011, s.513.

67 Özsaray, a.g.e., s.298.

${ }^{68}$ Nakşi tarikatından Şeyh Said Efendi'ye verilen bin beş yüz kuruş harcırah için bkz. BOA, C.EV.., 216/10776, H. 25.04.1250 (M. 31 Ağustos 1834); Fehmi Y1lmaz, "Harc-1 rah", Osmanl Tarih Sözlüğü, Gökkubbe Yayınları, İstanbul, 2017, s.220.

${ }^{69}$ Abdülkadir Özcan, "Hac", DİA, C.14, Ankara, 1996, s.400-408.

${ }^{70}$ BOA, HAT, 496/24364, H. 23.05.1237 (M. 15 Şubat 1822).

${ }^{71}$ Suraiya Faroqhı, Hacılar-Sultanlar (1517-1638), çev. Gül Çağalı Güven, TTK, Ankara, 1995, s.58;

Ş. Tufan Buzpinar, "Surre", DIA, C.37, Ankara, 2009, s.58, 567-569.

727 Ocak 1837 tarihinde biri kadınlara diğeri ise erkeklere mahsus olmak üzere hac yolculuğuna çıanlar için kervansaraylar inşa edilmiş ve buraya Nakşibendi tarikatından es-Seyyid Şeyh Mehmed Özbekî Efendi görevlendirilmiştir. BOA, C.EV.., 120/5995, H. 29.09.1252 (M. 7 Ocak 1837).

${ }^{73}$ Tanman, "Özbekler Tekkesi”, DİA, C.34, Ankara, 2007, s.121-123.
} 
ilişkileri sıkı tutmak, şeyhlerin ve müritlerin barınabilmelerini sağlamak ve tarikat çevrelerinin desteklerini almak adına Sultan tekke imar faaliyetlerine girişmiştir. ${ }^{74}$ Tekke ve zaviyeler; ticari yol güzergahlarına, ekonomik yönden önemli olan şehir ve bölgelere veya hacca gitmek için kervanların kullandıkları yol üstlerine inşa edilmiştir. ${ }^{75}$ Genellikle tekke ve zaviye inşaları ve masrafları; padişah, paşalar, vezirler, beyler, şeyhler, vakıflar, toplumun ileri gelenleri tarafından ya da devlet hazinesinden karşılanarak yapılmıştır.

II. Mahmud döneminde Nakşi tekke ve zaviye inşalarıyla ilgili Osmanlı Arşivi vesikaları arasında oldukça önemli bilgilere ulaşılmaktadır. Bu makalede, bunlara dair bazı örnekler verilerek devletin bu konudaki çabasını ve siyaset anlayışını göstermek amaçlanmıştır.

5 Ocak 1810 tarihli belgeye göre; Nakşibendi tarikatı şeyhlerinden olan Feyzullah Efendi Cizre'de bir tekke inşa ettirmiş ve şeyhe, devlet hazinesinden bin yüz on sekiz akçe verilmiştir. ${ }^{76}$ Otlukçu Yokuşu'nda Şeyhülislam Ömer Hulusi Efendi bir tekke inşa ettirmiştir. Bu tekkeyi, şeriat kurallarına uymaları ve dua etmeleri şartıyla Nakşibendi tarikatına tahsis etmiştir. ${ }^{77}$ Padişahın arabacıbaşılarından biri olan Arif Baba (ö. 1843), Sultanahmet'te hangi tarihlerde olduğu bilinmeyen bir tekke yaptırır. Bu tekkeyi İstanbul'un meşhur meczuplarından Nakşibendi tarikatı mensubu olan Düğümlü Baba mesken tuttuğundan, burası Düğümlü Baba ismiyle anılmaya başlamıştır. ${ }^{78}$ Çeşitli hizmetlerde bulunarak devlet kadrolarında görev alan Musa Safveti Paşa, 1845 tarihinde Eminönü'nde bağlı olduğu Halidiyye Tarikatı'na ait bir tekke inşa ettirmiştir. ${ }^{79}$ Ayrıca tekke ve zaviyelerin ihtiyaçlarına göre çeşme, cami ${ }^{80}$, kütüphane $^{81}$ veya harem dairesi ${ }^{82}$ inşa edilmiştir. Bu gibi örneklerden

${ }^{74}$ Özsaray, a.g.e., s.275.

${ }_{75}$ Necdet Y1lmaz, Osmanl Toplumunda Tasavouf: Sufiler, Devlet ve Ulemâ (17. Yüzyıl), OSAV, İstanbul,2007, s.440.

${ }^{76}$ BOA, C.EV.., 331/16838, H. 29.11.1224 (M. 5 Ocak 1810).

${ }_{77}$ Câbi Tarihi, haz. Mehmet Ali Beyhan, TTK, C.2, Ankara, 2003, s.912.

${ }^{78}$ Mustafa Tahralı, "Rifaiyye", Türkiye'de Tarikatlar ve Kültür, Ed. Semih Ceyhan, İsam Yayınları, İstanbul, 2018, s.231.

79 Yücer, a.g.e., s.559.

${ }^{80}$ Hacı Bektaş-i Veli Zaviyesi'ne şeyh olarak atanan Nakşibendi tarikatından Mehmed Said Efendi, 1836 yılında tekke içine bir cami-i şerif yapılmasını devletten istemesine dair bkz. BOA, HAT, 553/27362, H. 07.04.1251 (M. 2 Ağustos 1835); HAT, 553/27362, H. 29.12.1251 (M. 16 Nisan 1836).

${ }^{81}$ Mülkiye Nazırı Pertev Paşa Nakşibendi tarikatına bağlı olup, tarikatın Üsküdar'daki Selimiye Tekkesinin içine 4 Aralık 1835 tarihinde bir kütüphane inşa ettirmiştir. Butrus Abu Manneh, "19. Yüzyıl Başlarında Osmanlı Nakşî-Müceddîdilik", çev. Hür Mahmud Yücer, Tasavvuf İlmî ve Akademik Araştırma Dergisi, Ankara, 2004, s.283.

${ }^{82}$ Abdal Musa Zaviyesi'ne şeyh olarak atanan Nakşibendi tarikatından Halil Efendi'ye, devlet hazinesi tarafından bir hücre inşa edilmesine dair bkz. BOA, C.EV.., 132/6560, H. 17.11.1252 (M. 24 Şubat 1837). 
anlaşılacağı üzere 19. yüzyılda da devam eden tekke ve zaviye inşalarına, II. Mahmud'un ne kadar önem verdiğini görülmektedir. Tekke inşalarına önem verilmesinin sebebi ise; Nakşibendi tarikatına olan muhabbetin yanı sıra devletin kendini yenileme sürecinde tekke ahalisinin desteğini alma siyasetidir. ${ }^{83}$

Yangın, sel, deprem, kötü hava şartlar1 ${ }^{84}$ veya uzun bir zamandır bakımı yapılmaması gibi nedenlerden dolayı bazı Nakşibendi tekkelerinde tamir ve onarım işlemleri gerekli görülmüştür. ${ }^{85}$ Tamir ve onarım işlemleri, gerek devlet gerek vakıflar veya şahıslar tarafından karşılanmıştır. Aynı zamanda kimi şeyhler dergahlarının tamiri için borç almışlar ya da evlerini satarak tekke masraflarını karşılamışlardır. Tamir ve onarıma ihtiyacı olan Nakşi tekkeleri, şeyhin ve dervişlerin müracaat etmesi veyahut halktan kişilerin bildirmesi sonucunda tespit edilmiştir. Daha sonra Tamirat Müdürü tekkeyi yerinde keşfetmek, tamir için yapılacak muhtemel masrafı hesaplamak ve tekkenin tamirini ustalara yaptırmak için görevlendirilmiştir. Tekke ve zaviyelerde önemli gün ve gecelerin icra edilebilmesi ve tekkelerin halka çeşitli alanlarda hizmet veriyor olması gibi nedenlerden dolayı devlet tamirat işlemlerinde böyle hizmet gören tekkelere öncelik vermiştir. ${ }^{86}$

\section{Sonuç}

Bu çalışmada II. Mahmud döneminde Nakşibendi tekke ve zaviyelerine devlet, vakıflar, şahıslar tarafından yapılan yardımlar ele alınmıştır. Belgeler ve araştırma eserler 1şığında bu yardımların neler olduğu, miktarları, türleri, hangi tarihlerde verildikleri, tahsis edilen tekke ve zaviyelerin isimleri ortaya konmaya çalışılmıştır. Ayrıca Sultan tarafından vakıfları tek elde toplamak amacıyla kurulan Evkaf-ı Hümayun Nezareti'nin tekkelere karşı yürüttükleri hizmet faaliyetleri ve tekkelerin ekonomik yönden devlete bağıml hale gelmeleri üzerinde durulmuştur. Bu kapsamda tekkelerin dini, sosyal ve kültürel faaliyetlerinin neler olduğu ve hangi alanlarda hizmet verdiklerine de değinilmiştir.

\footnotetext{
83 Özsaray, a.g.e., s. 278.

${ }^{84}$ Sultan III. Selim tarafından 1805 'te inşa edilen ve Nakşibendi tarikatına tahsis edilen Selimiye Cami-i Şerif ve Külliyesi kötü hava şartlarından zarar görmüş ve 1834-1836 yılları arasında II. Mahmud tarafından yeniden inşa edilerek onarılmıştır. M. Baha Tanman, "Selimiye Tekkesi", DİA, C.36, Ankara, 2009, s.438-439; M. Gözde Ramazanoğlu, "Selimiye Cami ve Külliyesi", DİA, C.36, Ankara, 2009, s.434-436.

${ }^{85}$ Turhal'da Şeyh Mustafa Efendi'nin inşa eylediği Nakşibendi zaviyesinin tamiri ve hamamının onarımı için beş yüz bin guruş verilmesine dair bkz. BOA, C.EV.., 127/6308, H. 22.12.1237 (M. 9 Eylül 1822); Tekkelerin tamir ve onarımları için ayrıca bkz. BOA, C.EV.., 385/19514; HSD.AFT, 1/27; HAT, 1302/50755.

86 Varol, a.g.e., s.141-143.
} 
Araştırma sonucunda ise devletin kuruluş zamanında olduğu gibi 18081839 yılları arasında devlet ve Nakşi tarikatın dayanışma içerisinde olduğu, tarikatın irşad faaliyetlerinin yanında sosyo-kültürel faaliyetlerini devam ettirdikleri, devlet tarafından tarikata maddi-manevi çeşitli kolaylıklar sağlandığ 1 tespit edilmiştir. Devlet ve tarikatın birbirleri ile sürekli etkileşim halinde olduğu gerek tekke ve zaviye inşalarında gerekse yapılan yardımlarla açılamaya çalışılmıştır. Burada son tahlilde şunu belirtmek gerekir ki devlet tarafından Nakşi tekkelerine yapılan yardımların arka planında hem tekke ve ahalisini kontrol edebilmek hem de tarikatın desteğini almak gibi nedenler yatmaktadir.

\section{Kaynakça}

\section{Arşiv Belgeleri}

AE.SMHD.II. (Mahmud II): 64/4585; 93/7775; 115/9705.

C..BLD. (Belediye): 9/447; 43/2143.

C..DH.. (Dahiliye): 70/3496.

C..EV.. (Evkaf): 120/5995; 127/6308; 132/6560; 137/6807; 139/6946; 152/7570；216/10776；224/11195；226/11280；231/11501；242/12061; 244/12198; 277/12198; 298/15173; 305/15511; 331/16838; 332/16863; 345/17546; 385/19514; 423/21417; 496/25094; 530/26764; 561/28306; 605/30508.

C..ML.. (Maliye): 15/658; 77/3502; 780/31853.

C..SM.. (Saray): 32/1620.

HAT (Hatt-1 Hümayun): 496/24364; 527/25869; 544/26892; 553/27361; 553/27362; 719/34281; 756/35778; 1302/50752; 1302/50755; 1320/51539; 1513/73; $1553 / 45 ; 1568 / 44 ; 1652 / 1$.

HSD.AFT (Ali Fuat Türkgeldi Evrakı): 1/27.

İE.HAT (Hatt-1 Hümayun): 6/573; 6/588.

TS.MA.e (Topkapı Sarayı Müzesi Arşivi Evrakı): 1171/1.

\section{Diğer Kaynaklar}

Aslan, Halide; “Osmanlı İmparatorluğu'nda Mübarek Gün ve Gecelerden Kandiller", ISTEM, S.13, 2009, s.199-231.

Barkan, Ömer Lütfi; “Osmanlı İmparatorluğu'nda İmaret Sitelerinin Kuruluş ve İşleyiş Tarzına Ait Araştırmalar", İstanbul Üniversitesi İktisat Fakültesi Mecmuası, C.23, 1962-1963, s.274-276.

Berki, Şakir; "Vakıfların Gördüğü Çeşitli Hizmetler”, Vakıflar Dergisi, S.6, 1965, s.86-91. 
Bilgin, Arif; "Matbah-1 Amire", DİA, C.28, Ankara, 2003, s.115-119.

Bostan, İdris; “Tersane-i Amire”, DIA, C.40, Ankara, 2011, s.513-516.

Buzpinar, Ş. Tufan; “Surre”, DIAA, C.37, Ankara, 2009, s.567-569.

Cebecioğlu, Ethem; “Ta'am”, Tasavvuf Terimleri ve Deyimleri Sözlüğ̈̈, Rehber Yayınları, Ankara, 1997, s.679.

Câbî, Ömer Efendi; Câbî Tarihi, haz. Mehmet Ali Beyhan, TTK, Ankara, 2003.

Emecen, Feridun; "Fodula", DİA, C.13, Ankara, 1996, s.167-170.

Faroqhı, Suraiya; "Hacılar-Sultanlar (1517-1638)", çev. Gül Çağalı Güven, TTK, Ankara, 1995.

Günay, Hacı Mehmed; “Vakıf”, DİA, C.42, Ankara, 2012, s.475-479.

Gündüz, Filiz; “Okmeydanı”, DİA, C.33, Ankara, 2007, s.339-340.

Gündüz, İrfan; Osmanlılarda Devlet/Tekke Münasebetleri, Seha Neşriyat, İstanbul, 1989.

Işık, Zekeriya; Şeyhler ve Şahlar, Çizgi Yayınları, Konya, 2015, s.24-25.

Tekkedeki İktidar, Çizgi Yayınları, Konya, 2017, s.119.

İpşirli, Mehmet; "II. Mahmud Döneminde Vakıfların İdaresi", Sultan II. Mahmud ve Reformları Semineri, İstanbul, 1990, s.49-57.

Kara, Mustafa; “Tekke”, DIA, C.40, Ankara, 2011, s.368-370.

Tekkeler ve Zaviyeler, Dergah Yayınları, İstanbul, 2005.

Köprülü, M. Fuat; "Vakıf Müessesesinin Hukuki Mahiyeti ve Tarihi Tekamülü", Vakıflar Dergisi, S.2, 1942, s.23-24.

Küçük, Hasan; Osmanlı Devleti'ni Tarih Sahnesine Çıkaran Kuvvetlerden Biri; Tarikatlar ve Türkler Üzerindeki Müsbet Tesirleri, TÜRDAV Yayınları, İstanbul, 1976.

Manneh, Butrus Abu; “19, Yüzyıl Başlarında Osmanlı'da NakşîMüceddîdilik", çev. Hür Mahmud Yücer, Tasavvuf İlmî ve Akademik Araştırma Dergisi, 2004, s.283.

Özcan, Abdülkadir; "Güreş”, DİA, C.14, Ankara, 1996, s.317-320. "Hac", DİA, C.14, Ankara, 1996, s.400-408.

Özel, Ahmet; "Mevlid”, DIA, C.29, Ankara, 2004, s.475-479. 
Özer, Ekrem; Osmanlı'da Tekke ve Tarikat Islahatları II. Mahmud Dönemi ve Sonrası, Atatürk Üniversitesi Sosyal Bilimler Enstitüsü, Doktora Tezi, Erzurum, 2007.

Özsaray, Mustafa; Arşiv Belgeleri Işı̆̆ında Osmanlı'da Devlet-Tekke İlişkileri (XIX. Yüzyıl), Fatih Sultan Mehmet Vakıf Üniversitesi Sosyal Bilimler Enstitüsü, Doktora Tezi, İstanbul, 2018.

Öztürk, Nazif; “Evkaf-1 Hümayun Nezareti”, DİA, C.11, Ankara, 1995, s.521-524.

Pakalın, Mehmet Zeki; "Taamiye”, Osmanlı Tarih Deyimleri ve Terimleri Sözlü̆̆̈̈, MEB, C.3, İstanbul, 1983, s.363. “Muharremiyye", C.2, s.566-567.

Ramazanoğlu, M. Gözde; "Selimiye Cami ve Külliyesi", DIA, C.36, Ankara, 2009, s.434-436.

Şeker, Mehmed; "Mevlid”, DİA, C.29, Ankara, 2004, s.479-480.

Tahralı, Mustafa; "Rifaiyye", Türkiye'de Tarikatlar ve Kültür, ed. Semih Ceyhan, İsam Yayınları, İstanbul, 2018.

Tanman, M. Baha - Parlak, Sevgi; “Tekke”, DIA, C.40, Ankara, 2011, s.370-379.

Tanman, M. Baha; “Hindiler Tekkesi”, DİA, C.18, Ankara, 1998, s.67-69. “Özbekler Tekkesi”, DIA, C.34, Ankara, 2007, s.123-124. “Selimiye Tekkesi", DIA, C.36, Ankara, 2007, s.438-439.

Uzun, Mustafa İsmet; “Miraciyye”, DİA, C.30, Ankara, 2005, s.135-140.

Ünal, Mehmet Ali; “Navlun”, Osmanlı Tarih Sözlüğ̈̈, Paradigma Yayınları, İstanbul, 2011, s.513.

Varol, Muharrem; Bektaşilik İlgası Sonrasında Osmanlı Devleti'nin Tarikat Politikaları (1826-1866), Marmara Üniversitesi Türkiyat Araştırmaları Enstitüsü, Doktora Tezi, İstanbul, 2011.

Yaşaroğlu, M. Kamil; “Muharrem”, DIA, C.31, Ankara, 2006, s.4-5.

Yavuz, Salih Sabri; "Mir'ac", DİA, C.30, Ankara, 2005, s.133-135.

Yılmaz, Fehmi; “Harc-1 rah”, Osmanlı Tarih Sözlüğ̈̈, Gökkubbe Yayınları, İstanbul, 2017, s.220.

Y1lmaz, Necdet; “Osmanlı Toplumunda Tasavvuf: Sufiler, Devlet ve Ulemâ (17. Yüzyıl), OSAV, İstanbul, 2007. 
Yılmaz, Ömer; Geçmişten Günümüze Tasavvuf ve Tarikatlar, Akçă̆ Yayınları, Ankara, 2019.

Yıldırım, Nuran; “Miskinler Tekkesi”, DIA, C.30, Ankara, 2005, s.185-186.

Yücer, Hür Mahmud; Osmanl Toplumunda Tasavouf (19. Yüzyll), İnsan Yayınları, İstanbul, 2002. 
Ekler

Ek-1

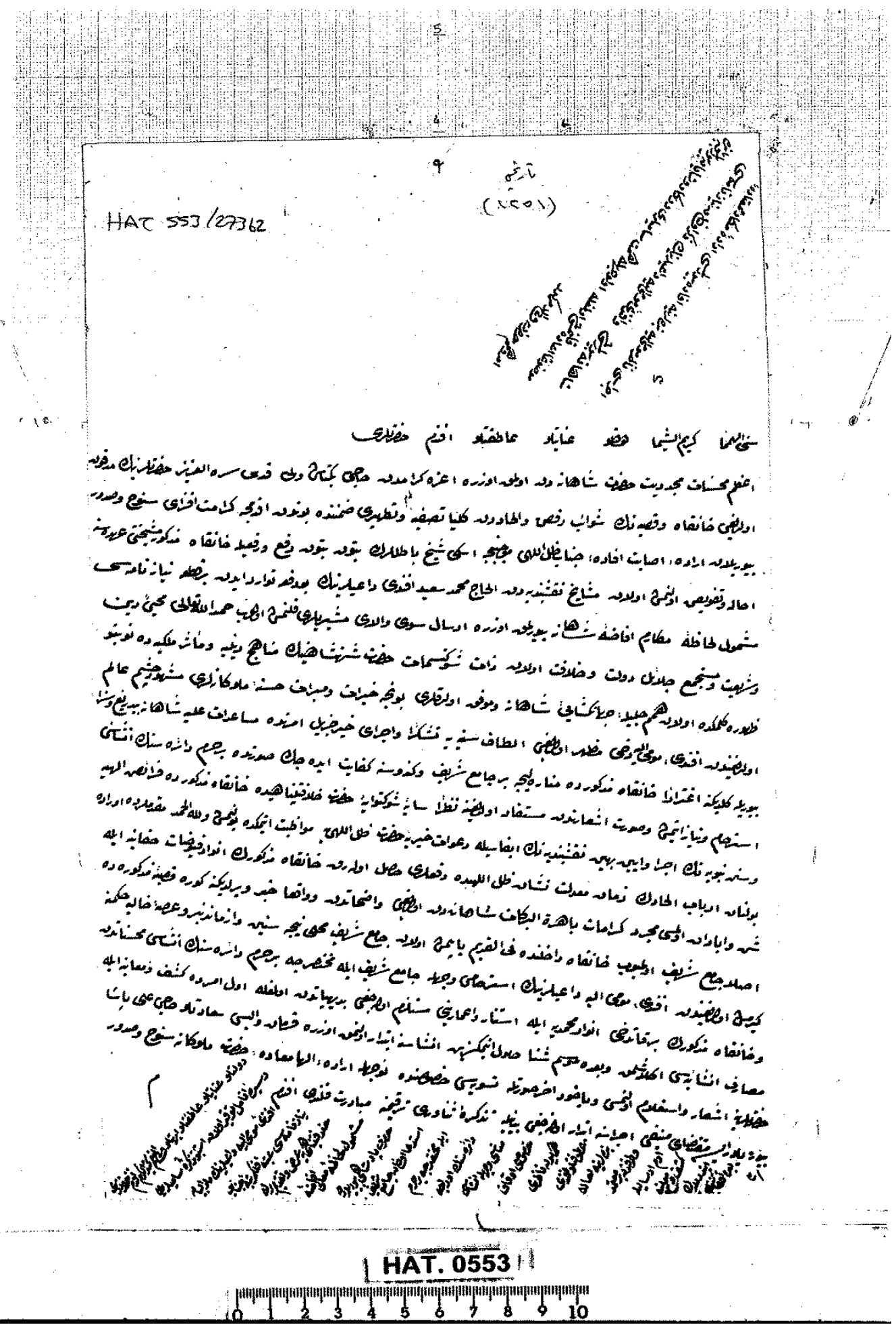

Hacı Bektaş-i Veli Zaviyesi'ne şeyh olarak atanan Nakşibendi tarikatından Mehmed Said Efendi'ye harem dairesi ve tekke içerisine cami yapılmasına dair. 


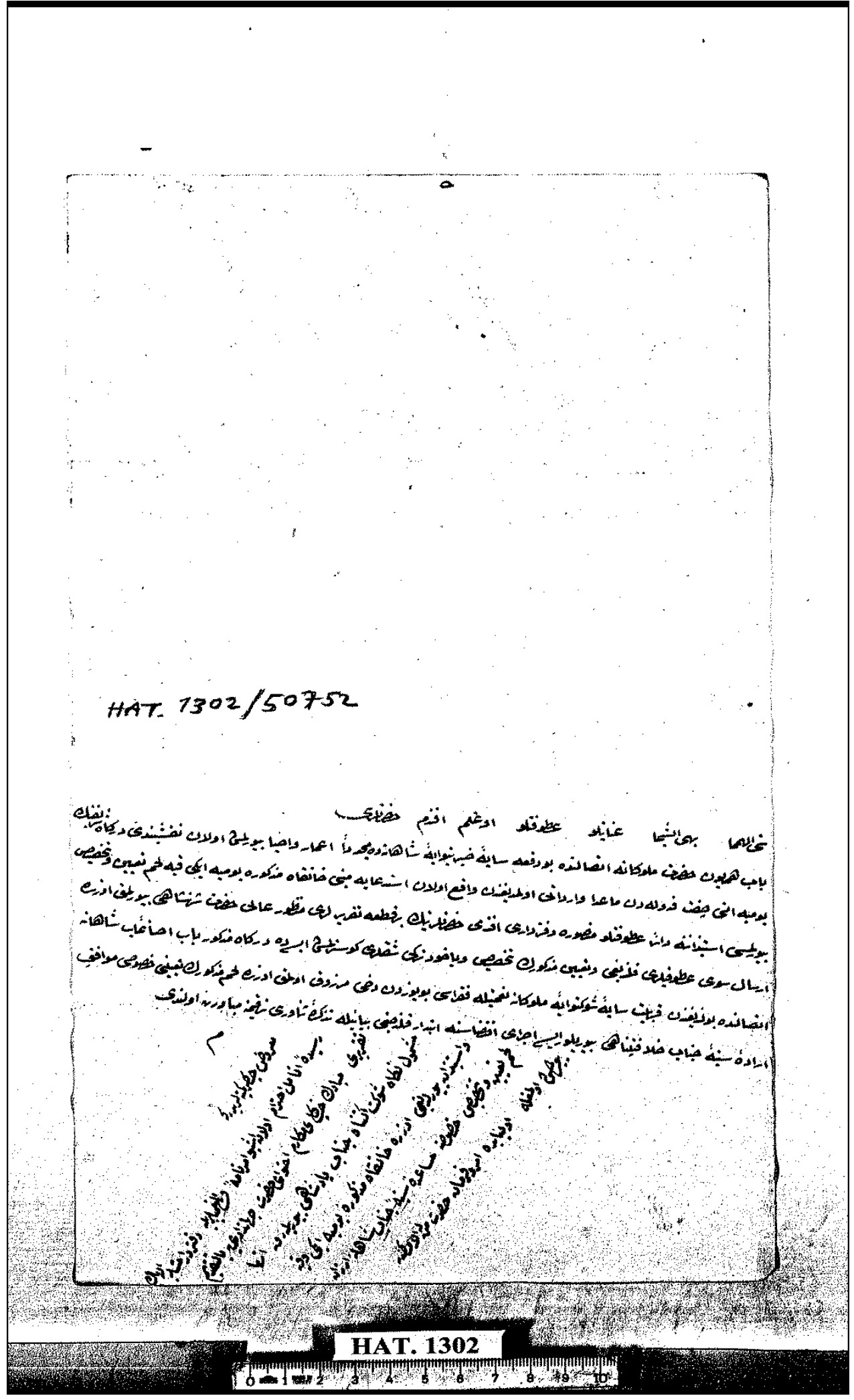

Bab-1 Hümayun yanında bulunan Nakşibendi dergahına iki kıyye et tahsisi yapıldığına dair. 